\title{
PSIKOLOGI MASYARAKAT INDONESIA DI TENGAH PANDEMI: SEBUAH STUDI ANALISIS KONDISI PSIKOLOGIS MENGHADAPI COVID-19 PERSPEKTIF COMFORT ZONE THEORY
}

\author{
${ }^{1}$ Talolo Muara, ${ }^{2}$ Triyoga Budi Prasetyo, ${ }^{3}$ Hayatul Khairul Rahmat \\ ${ }^{1}$ Program Studi Magister Peperangan Asimetris, Fakultas Strategi Pertahanan, \\ Universitas Pertahanan, Bogor, Indonesia \\ ${ }^{2,3}$ Program Studi Bimbingan dan Konseling Islam, Fakultas Dakwah dan Komunikasi, \\ Universitas Islam Negeri Sunan Kalijaga, Yogyakarta, Indonesia \\ E-mail: talolo.muara@idu.ac.id
}

\begin{abstract}
The designation of COVID-19 as a pandemic has a psychological impact on people around the world. Therefore, this paper aims to analyze the psychological development of the Indonesian people towards the COVID-19 policy in Indonesia based on the comfort zone theory. The method used in this research is the literature method with content analysis as the blade of analysis. The findings of this study are that the psychological phase of Indonesian society in general is at the stage of growth power. However, there are still a small proportion of people who tend to ignore policies such as the prohibition of the Eid homecoming which causes the social distancing policy to not run optimally.
\end{abstract}

Keywords: Comfort Zone Theory, COVID-19 Pandemic, Indonesian Society, Psychological Condition.

\begin{abstract}
Abstrak: Penetapan COVID-19 sebagai pandemi menimbulkan dampak psikologis bagi masyarakat seluruh dunia. Oleh karena itu, tulisan ini bertujuan untuk menganalisis perkembangan psikologis masyarakat Indonesia terhadap kebijakan COVID-19 di Indonesia berdasarkan comfort zone theory. Metode yang digunakan dalam penelitian ini adalah metode kepustakaan dengan analisis konten sebagai pisau analisisnya. Adapun temuan dari penelitian ini adalah fase psikologis masyarakat Indonesia secara umum berada pada tahap growth power. Akan tetapi, masih terdapat sebagian kecil masyarakat yang cenderung mengabaikan kebijakan seperti larangan mudik lebaran yang menyebabkan kebijakan social distancing tidak berjalan secara maksimal.
\end{abstract}

Kata Kunci: Comfort Zone Theory, Kondisi Psikologis, Masyarakat Indonesia, Pandemi COVID-19.

\section{Pendahuluan}

Penetapan COVID-19 sebagai pandemi menimbulkan dampak psikologis bagi masyarakat seluruh dunia (Perry, Whitehead, \& Grubbs, 2020). Pandemi merujuk pada peningkatan jumlah kasus penyakit pada populasi daerah tertentu dan telah menyebar ke beberapa negara atau benua (Rahmat \&
Alawiyah, 2020). Merespon hal tersebut, pemerintah seluruh negara menerapkan kebijakan baik social distancing, physical distancing, hingga lockdown. Namun demikian, masifnya penyebaran konten terkait di COVID 19 menimbulkan dampak psikologis bagi masyarakat dunia termasuk Indonesia.

Coronavirus merupakan virus yang terdapat pada hewan dan umumnya tidak 
ditularkan kepada manusia. Coronavirus Disease 2019 disebabkan oleh virus SARSCoV-2 yang pertama kali ditemukan di Kota Wuhan, Provinsi Hubei, Republik Rakyat Tiongkok pada awal Desember 2019 (Rahmat et al., 2020). Namun demikian, World Health Organization atau Badan Kesehatan Dunia dan para ahli berasumsi bahwa hewan liar sebagai medium penyebar virus SARS-CoV-2 yang menyebakan penyakit COVID-19 (Junaedi \& Salistia, 2020; Kurniawan HS, Amrullah, Salahuddin, Muslim, \& Nurhidayanti, 2020).

Melihat kondisi seperti ini, pemerintah perlu mengantisipasi kemampuan psikologis individu masyarakat, baik pasien positif maupun masyarakat umum terhadap COVID-19. Perlu adanya strategi coping adaptif dan coping maladaptif (Hanum, 2020). Coping adaptif berkaitan dengan kemampuan individu untuk melindungi diri secara tepat yaitu mendekatkan diri kepada Tuhan. Namun di sisi lain, coping maladaptif berkaitan dengan ketidakmampuan individu untuk melindungi diri sehingga mengakibatkan distress, kecemasan, dan obsesif kompulsif (kekhawatiran berlebihan). Oleh karena itu, pemerintah memerlukan strategi yang tepat menghadapi kemampuan psikologis masyarakat yang berbeda-beda (Muhyiddin, 2020).

Pasien terkonfirmasi positif COVID-19 pertama kali di Indonesia adalah warga Kota Depok yang terpapar dari turis Jepang. Hal ini dapat dilihat pada Gambar 1.

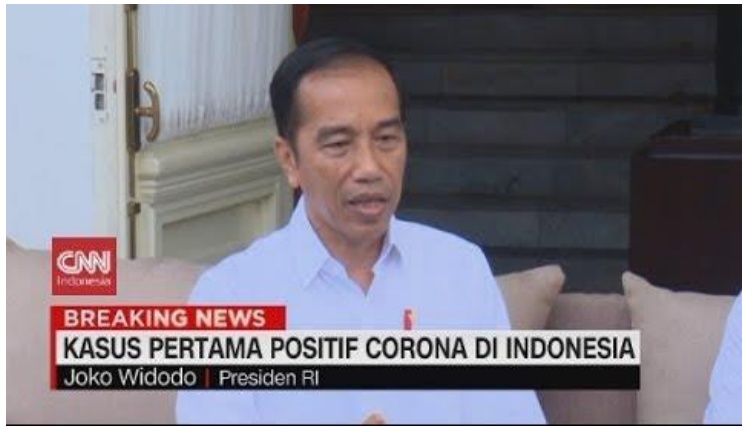

Gambar 1: Kasus Pertama Positif COVID-19 di Indonesia

Kondisi ini mengakibatkan masyarakat terserang panic buying sehingga membeli masker, hand sanitizer, dan makanan pokok secara berlebihan. Pasien positif COVID-19 akan terserang dampak, baik secara secara fisik dan psikis. Rini Setyowati selaku dosen Program Studi Psikologi Kedokteran Universitas Negeri Surakarta menyatakan bahwa pasien terkonfirmasi positif COVID-19 mengalami dampak psikologis di antaranya perasaan tertekan dan cemas ketika privasi dan identitasnya diketahui publik serta takut dikucilkan (Pratama \& Hidayat, 2020; Rayani \& Purqoti, 2020).

Selain itu, pemberitaan yang simpang siur dan belum teruji kebenarannya mendorong bangkitnya hormon stres yang mengakibatkan imun menurun dan rentan terhadap COVID-19 (Fuqohak \& Amiruddin, 2021; Imhoff \& Lamberty, 2020; N. F. Putri, Vionia, \& Michael, 2020). Namun demikian, terdapat pasien terkonfirmasi COVID-19 yang tidak acuh terhadap mengisolasi diri di rumah sehingga rantai penyebaran virus terus berlanjut.

Serangan psikologis tidak hanya terjadi pada pasien terkonfirmasi positif COVID-19. 
Seluruh masyarakat Indonesia turut merasakan insecure (rasa tidak aman) dan mungkin mengalami psikosomatis (sugesti fisik akibat kecemasan mental seperti sesak napas). Hal ini mengakibatkan banyak masyarakat yang melakukan panic buying, mudahnya percaya akan berita hoax, dan menghindari hubungan sosial.

Jakarta menjadi episentrum utama penyebaran COVID-19. Gubernur DKI Jakarta sempat hendak menetapkan status darurat Jakarta. Namun demikian, berdasarkan Undang-Undang Republik Indonesia Nomor 6 Tahun 2018 Tentang Karantina Kesehatan yang menyatakan bahwa keputusan karantina wilayah menjadi kewenangan Presiden. Kemudian, pada tanggal 3 Maret 2020, Menteri Kesehatan, Agus Terawan Purwanto telah menandatangani Peraturan Menteri Kesehatan Nomor 9 Tahun 2020 Tentang Pembatasan Sosial Berskala Besar Dalam Rangka Percepatan Penanganan COVID-19. Namun demikian, Joko Widodo selaku Presiden Indonesia menegaskan bahwa pemerintah tidak memilih lockdown karena mengganggu perekonomian. Adapun dampak dari penerapan penerapan Pembatasan Sosial Berskala Besar (PSBB) yaitu adanya social distancing karena masyarakat yang terbiasa untuk menghabiskan waktu untuk bercengkrama dan beraktivitas di luar rumah cenderung merasa terpenjara (Hidayat, Gustini, \& Dias, 2020; Pratama \& Hidayat, 2020).

Berdasarkan paparan di atas, penulis akan menganalisis perkembangan psikologis masyarakat Indonesia terhadap kebijakan COVID-19 di Indonesia berdasarkan comfort zone theory.

\section{Metode Penelitian}

Tulisan ini disusun menggunakan metode kepustakaan (library research). Library research ini dilakukan dengan mengumpulkan berbagai referensi bacaan yang relevan dengan permasalahan yang diteliti, kemudian dilakukan pemahaman cara teliti dan careful sehingga mendapatkan sebuah temuan-temuan penelitian (Hakim, Banjarnahor, Purwanto, Rahmat, \& Widana, 2020; Marufah, Rahmat, \& Widana, 2020; H. R. Putri, Metiadini, Rahmat, \& Ukhsan, 2020). Penulis melakukan studi literatur secara mendalam untuk mendukung penelitian ini dan menggunakan analisis isi (content analysis) (Rahmat, 2019; Utama, Prewito, Pratikno, Kurniadi, \& Rahmat, 2020). Adapun model interaktifnya dijelaskan dalam

\section{Gambar 2.}

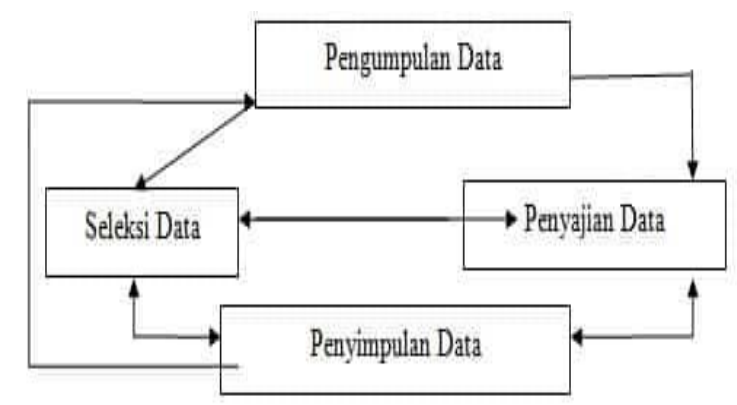

Gambar 2: Model Interaktif Analisis Konten

HaSil Dan PEMbahasan

Teori Comfort Zone: Sebuah Kerangka Konseptual 
Setiap zona mewakili pencapaian pola pikir baru. Kebanyakan orang nyaman berada dalam comfort zone karena situasi aman dan terkendali. Tantangan yang dihadapi pada fase comfort zone, akan berlanjut pada tahap fear zone. Pada fase tersebut, kita akan merasa kurang percaya diri dan membuat alasan untuk kembali pada comfort zone (Agung, 2020). Adapun comfort zone theory dapat dijelaskan pada Gambar 3.

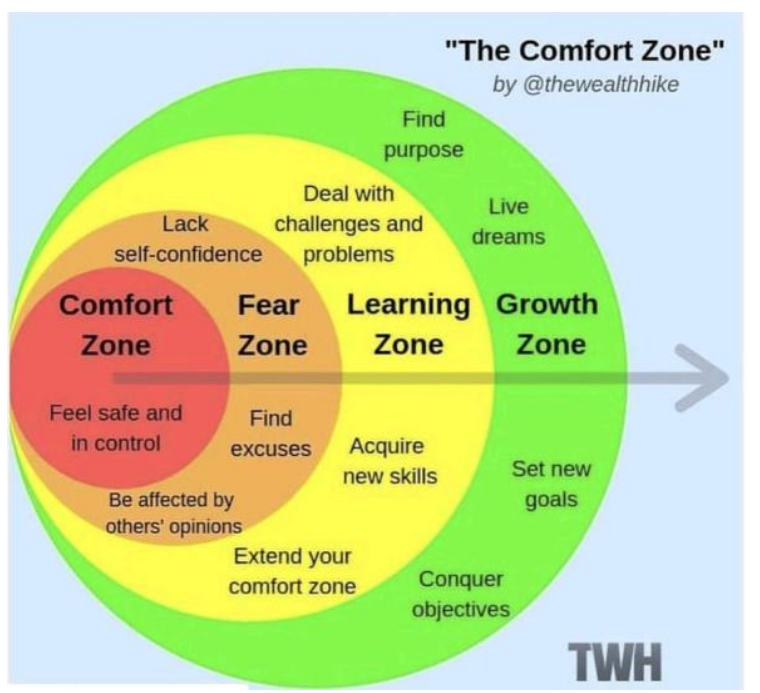

Gambar 3: Comfort Zone Theory

Fear zone merupakan fase sementara yang akan membawa pada pola pikir yang lebih baik. Saat sudah melewati fase keberanian, percaya diri, dan berhenti membuat alasan, maka akan bergeser ke tahap learning zone.

Learning zone adalah zona dimana kita memperoleh keterampilan dan pengalaman baru dan mencapai yang belum terpikirkan sebelumnya. Setelah melewati tahap ini, kita akan menuju pada growth zone. Pada tahap growth zone, kita akan memiliki motivasi untuk menetapkan tujuan dan sasaran baru yang diyakini akan dicapai. Selain itu, kita juga mampu untuk membawa orang menuju pada growth zone. Pada fase ini, kita akan sering bertemu dengan orang yang berpikiran sama growth zone.

Wakil Ketua Himpunan Psikologi Indonesia (HIMPSI) Cabang Malang, Isa Wahyudi (dalam Handayani, Kuntari, Darmayanti, Widiyanto, \& Atmojo, 2020) menyebutkan bahwa terdapat tiga tahap yang dilalui psikis saat menghadapi pandemi COVID-19. Pertama, fear zone (ketakutan) yaitu kondisi masyarakat mudah terteror akan berita hoaks dan membagikannya melalui platform media sosial sehingga mengakibatkan panic buying dan belanja berlebihan (Rahayu \& Sensusiyati, 2020; Rianto, 2019; Sabani, 2018). Kedua, learning zone (masa belajar) yaitu suatu kondisi masyarakat mulai menyadari situasi dan diri sendiri sehingga mematuhi aturan pemerintah, mampu mengendalikan emosi, tidak belanja berlebihan, dan merencanakan tindakan dengan baik. Ketiga, growth zone (masa tumbuh) yaitu kondisi masyarakat mulai memikirkan dan berempati satu sama lain terkait pandemi COVID-19.

Analisis Tahapan Psikis Menghadapi Pandemi COVID-19

Pertama, fear zone (fase ketakutan). Kesehatan fisik dan mental penting dalam menghadapi COVID-19. Mayoritas masyarakat terpengaruh dan terpapar ketakutan melalui konten pada platform media sosial terkait pasien positif COVID-19 di luar negeri (Dai, 
2020). Kecemasan dan kepanikan semakin memuncak pasca Presiden Joko Widodo mengumumkan dua warga Depok terpapar COVID-19 pada 2 Maret 2020.

Kemunculan pasien positif COVID-19 menimbulkan panic buying di masyarakat. Palupessy menyebutkan bahwa panic buying adalah kondisi masyarakat membeli barang secara berlebihan dalam satu waktu. Panic buying tersebut merupakan mekanisme psikologis ketika masyarakat kehilangan sense of control. Namun demikian, panic buying ini wajar karena COVID-19 sering kali dikaitkan dengan kematian dan belum adanya vaksin sehingga cenderung bertindak cepat dan impulsive dorongan psikologis untuk bertindak cepat karena belum adanya vaksin COVID-19.

Selain itu, kondisi ini mengakibatkan masyarakat sensitif, terpengaruh, dan mudah percaya terhadap informasi hoaks atau berita bohong (Hannan \& Muhaimin, 2020; Harirah \& Rizaldi, 2020; Zulfa \& Laras, 2020). Pada awal-awal pandemi COVID-19, masyarakat cenderung mudah terserang distress. Mirowsky dan Ross (dalam HM, 2012) menyatakan bahwa distress adalah keadaan subjektif yang tidak menyenangkan. Hal ini digambarkan dalam dua bentuk yaitu depresi dan kecemasan.

Menurut Fitria \& Ifdil (2020), faktor yang mempengaruhi distress yaitu sebagai berikut.

1. Fisiologis yaitu kerusakan pada amygdala yang mengakibatkan respon-respon emosional yang ekstrem dan kerusakan lobus frontalis yang mengakibatkan gangguan respon emosional dan hilangnya kontrol perilaku.

2. Kognitif berkaitan penilaian individu terhadap dirinya tidak memiliki kontrol dalam menghadapi peristiwa yang dianggap penting.

3. Sosial berkaitan dengan gangguan hubungan sosial seperti berduka, perselisihan keluarga, dan pengangguran.

4. Kepribadian yaitu suasana hati trait neuroticism yang memprediksi suasana hati negatif seperti depresi dan kecemasan.

Agar tidak mengalami distress atau panik sehingga perlu untuk melakukan berbagai hal seperti dijelaskan Gambar 4.

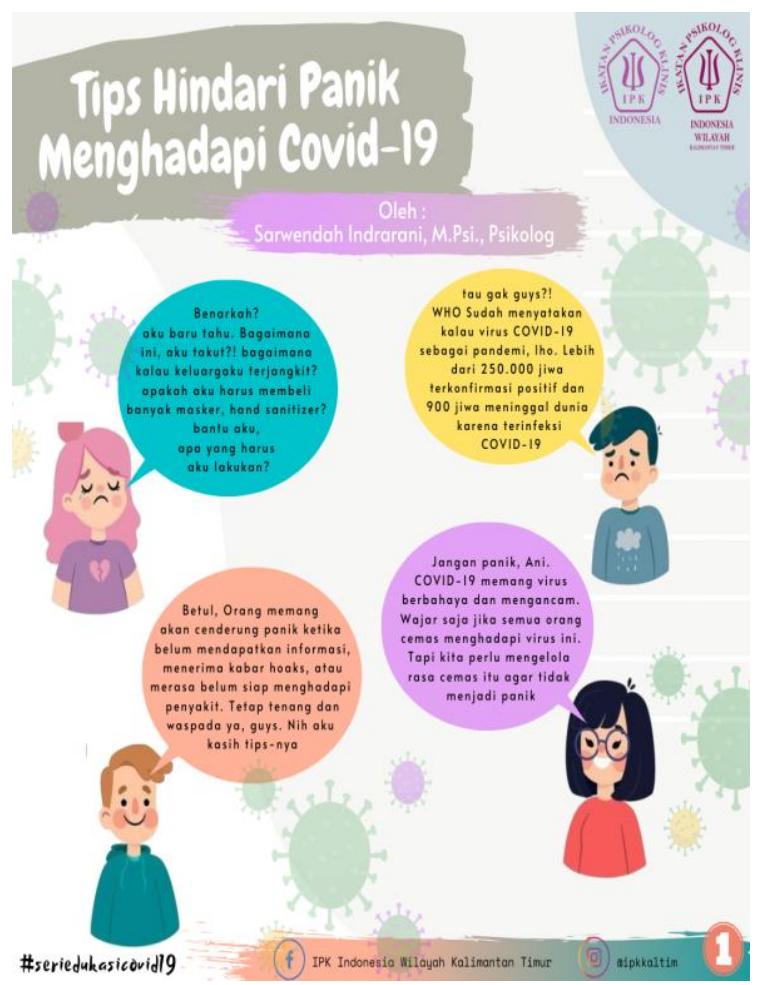

Gambar 4: Cara Menghindari Panik dalam Menghadapi COVID-19

Kedua, Fase learning zone berkaitan dengan fase masyarakat mulai mematuhi 
kebijakan pemerintah, mampu mengendalikan diri, dan bisa mengatur tindakannya lebih baik. Selain itu, masyarakat juga sudah mampu mengolah informasi dan data sehingga tidak mudah terpengaruh dan berdampak pada kegelisahan. Salah satunya adalah kebijakan social distancing yang berpengaruh terhadap kondisi mental individu masyarakat. Manusia sebagai makhluk sosial mengeluarkan kadar hormon oksitosin yang mengatur ikatan sosial masyarakat (Mutia, 2017; Witro, 2019).

Social distancing telah menghambat kinerja hormon oksitosin sehingga mengganggu kesehatan mental sehingga merasa merasa kehilangan, kesepian, perubahan nafsu makan, dan perubahan mood. Pasca penetapan physical distancing, masyarakat Indonesia cenderung menggunakan menggunakan aplikasi meeting jarak jauh. Terdapat beberapa aplikasi yang digunakan oleh masyarakat yaitu sebagai berikut.

1. WhatsApp. Aplikasi ini dapat bertukar pesan, multimedia, dan tatap muka melalui video. Aplikasi ini tidak mengeluarkan biaya karena terkoneksi dengan internet (Sutarto, Sari, \& Fathurrochman, 2020).

2. Google Duo adalah aplikasi panggilan video dengan kualitas tinggi. Google Video dapat melakukan panggilan grup yang maksimal 8 partisipan, panggilan dapat terhubung melalui ponsel, tablet, dan web, mode cahaya rendah, dapat mengirim pesan suara dan panggilan suara.

3. Skype adalah aplikasi panggilan suara dan video yang maksimal terhubung dengan 24

devicel perangkat dengan kualitas High Definition (HD). Selain itu dapat digunakan untuk pesan teks dari komputer atau ponsel.

4. Zoom Cloud Meeting adalah aplikasi pendukung pembelajaran online yang mampu menampung hingga 100 partisipan. Selain itu, Zoom dapat digunakan dalam konferensi radio karena memiliki keunggulan kualitas gambar (Syarifudin, 2020).

5. Hangouts adalah aplikasi yang dapat melakukan video call maksimal 10 partisipan dan obrolan suara sebanyak 150 partisipan.

Ketiga, fase growth zone merupakan kondisi masyarakat mulai menerima keadaan dan mulai memperhatikan orang lain. Masyarakat mulai memberikan dampak positif bagi lingkungan dan sesamanya. Pada zona ini, masyarakat turut mendorong kerabat, teman, maupun orang lain disekitarnya untuk turut membantu garda terdepan penangan COVID-19 dan pihak yang harus turun ke jalan.

Kebijakan social distancing memberikan dampak positif terhadap solidaritas masyarakat (Pradana, Casman, \& Nur'aini, 2020). Kondisi ini menimbulkan kepedulian masyarakat terhadap pengemudi online, menjahit alat pelindung diri untuk petugas medis, dan bantuan. Kondisi ini mencerminkan kekuatan nasional bangsa Indonesia yaitu gotong-royong dan persatuan.

\section{Penutup}


COVID-19 merupakan sebuah pandemi yang menimbulkan ketakukan psikologis seluruh masyarakat baik pasien positif COVID19 maupun masyarakat secara luas. Secara umum, fase psikologis masyarakat Indonesia berada pada tahap growth power. Akan tetapi, masih terdapat sebagian kecil masyarakat yang cenderung mengabaikan larangan mudik lebaran sehingga kebijakan social distancing tidak berjalan secara maksimal.

\section{DAFTAR RUJUKAN}

Agung, I. M. (2020). Memahami Pandemi Covid-19 Dalam Perspektif Psikologi Sosial. Psikobuletin:Buletin Ilmiah Psikologi, 1(2), 68-84. Retrieved from http://ejournal.uin-

suska.ac.id/index.php/Psikobuletin/article/ view/9616/5058

Dai, N. F. (2020). Stigma Masyarakat Terhadap Pandemi Covid-19. PROSIDING SEMINAR NASIONAL PROBLEMATIKA SOSIAL PANDEMI COVID-19 "Membangun Optimisme Di Tengah Pandemi Covid-19," 66-73.

Fitria, L., \& Ifdil, I. (2020). Kecemasan remaja pada masa pandemi Covid-19. Jurnal EDUCATIO: Jurnal Pendidikan Indonesia, 6(1), 1-4. https://doi.org/10.29210/120202592

Fuqohak, M. A. Z., \& Amiruddin, M. (2021). SOCIO-GENETIC MOTIVES OF MUI'S FATWA REGARDING COVID-19 BASED ON QURAN-HADITH. Jurnal Studi Ilmu-Ilmu Al-Qur'an Dan Hadis, 22(1), 19-48. Retrieved from file://C:/Users/ASUS/Downloads/Kasih

Sayang dalam Perspektif Agama Agama_Buku dan Artikel/Artikel_Nilai Cinta Kasih 2020/INTERNALISASI_HADIS_KASIH _SAYANG_DALAM_MEWUJUDKAN_ .pdf

Hakim, F. A., Banjarnahor, J., Purwanto, R. S., Rahmat, H. K., \& Widana, I. D. K. K.
(2020). Pengelolaan obyek pariwisata menghadapi potensi bencana di Balikpapan sebagai penyangga ibukota negara baru. Nusantara: Jurnal Ilmu Pengetahuan Sosial, 7(3), 607-612. https://doi.org/10.31604/jips.v7i3.2020.60 7-612

Handayani, R. T., Kuntari, S., Darmayanti, A. T., Widiyanto, A., \& Atmojo, J. T. (2020). Factors Causing Stress in Health and Community When the Covid-19 Pandemic. Jurnal Keperawatan Jiwa, 8(3), 353-360. https://doi.org/10.26714/jkj.8.3.2020.353360

Hannan, A., \& Muhaimin, W. (2020). Teologi Kemaslahatan Social-Phsycal Distancing dalam Penanggulangan Covid-19. KURIOSITAS: Media Komunikasi Sosial Dan Keagamaan, 13(1), 78-102. Retrieved from https://jurnal.ugm.ac.id/jkki/article/view/5 5575

Hanum, F. (2020). Dampak covid 19 terhadap psikologis masyarakat modern. Prosiding Seminar Nasional Webinar Nasional Universitas Mahasaraswati Denpasar "Percepatan Penanganan COVID-19 Berbasis Adat Di Indonesia," 85-87.

Harirah, Z., \& Rizaldi, A. (2020). Merespon Nalar Kebijakan Negara Dalam Menangani Pandemi Covid 19 Di Indonesia. Jurnal Ekonomi Dan Kebijakan Publik Indonesia, 7(1), 36-53. https://doi.org/10.24815/ekapi.v7i1.17370

Hidayat, D., Gustini, L. K., \& Dias, M. P. (2020). Digital Media Relations Pendekatan Public Relations dalam Menyosialisasikan Social Distancing di Kota Bandung. Jurnal Ilmu Komunikasi, 18(3), 257-268. https://doi.org/10.31315/jik.v18i3.3575

HM, M. (2012). Stres Kerja Dan Kinerja Dalam Perspektif Teori Dan Bukti Empirik. Jurnal Ekonomika Bisnis, 03(02), 111120. https://doi.org/10.22219/jekobisnis.v3i2.2 234

Imhoff, R., \& Lamberty, P. (2020). A Bioweapon or a Hoax? The Link Between 
Distinct Conspiracy Beliefs About the Coronavirus Disease (COVID-19) Outbreak and Pandemic Behavior. Social Psychological and Personality Science, 11(8), $1110-1118$. https://doi.org/10.1177/194855062093469 2

Junaedi, D., \& Salistia, F. (2020). Dampak Pandemi Covid-19 Terhadap Pasar Modal Di Indonesia: Studi Kasus Indeks Saham Komposit (ISHG). Al-Kharaj: Jurnal Ekonomi, Keuangan \& Bisnis Syariah, 2(2), $109-138$ https://doi.org/10.47467/alkharaj.v2i2.112

Kurniawan HS, H., Amrullah, A., Salahuddin, M., Muslim, M., \& Nurhidayanti, S. (2020). KONSEP KEBIJAKAN STRATEGIS DALAM MENANGANI EKSTERNALITAS EKONOMI DARI COVID-19 PADA MASYARAKAT RENTAN DI INDONESIA. Indonesian Journal of Social Sciences and Humanities, 1(2), 130-139. Retrieved from

file:///C:/Users/User/Downloads/fvm939e. pdf

Marufah, N., Rahmat, H. K., \& Widana, I. D. K. K. (2020). Degradasi modal sebagai dampak kejahatan siber pada generasi millenial di Indonesia. Nusantara: Jurnal Ilmu Pengetahuan Sosial, 7(1), 191-201. https://doi.org/10.31604/jips.v7i1.2020.19 $1-201$

Muhyiddin, M. (2020). Covid-19, New Normal dan Perencanaan Pembangunan di Indonesia. The Indonesian Journal of Development Planning Volume, IV(2), 240-252. https://doi.org/10.1016/j.cpha.2021.01.00 2

Mutia, T. (2017). Generasi Milenial, Instagram Dan Dramaturgi: Suatu Fenomena Dalam Pengelolaan Kesan Ditinjau Dari Perspektif Komunikasi Islam. An-Nida', 41(2), 240-251.

Perry, S. L., Whitehead, A. L., \& Grubbs, J. B. (2020). Culture Wars and COVID-19 Conduct: Christian Nationalism, Religiosity, and Americans' Behavior During the Coronavirus Pandemic.
Journal for the Scientific Study of Religion, 59(3),

https://doi.org/10.1111/jssr.12677 405-416.

Pradana, A. A., Casman, C., \& Nur'aini, N. (2020). PENGARUH KEBIJAKAN SOCIAL DISTANCING PADA WABAH COVID-19 TERHADAP KELOMPOK RENTAN DI INDONESIA. JURNAL KEBIJAKAN KESEHATAN INDONESIA: JKKI, 09(02), 61-67.

Pratama, N. A., \& Hidayat, D. (2020). Pengetahuan dan Perilaku Masyarakat Memaknai Social Distancing. Jurnal Digital Media \& Relationship, 2(1), 1-10.

Putri, H. R., Metiadini, A., Rahmat, H. K., \& Ukhsan, A. (2020). Urgensi pendidikan bela negara guna membangun sikap nasionalisme pada generasi millenial di Indonesia. Al-Muaddib: Jurnal Ilmu-Ilmu Sosial Dan Keislaman, 5(2), 257-271. https://doi.org/10.31604/muaddib.v5i2.25 7-271

Putri, N. F., Vionia, E., \& Michael, T. (2020). Pentingnya Kesadaran Hukum Dan Peran Masyarakat Indonesia Dalam Menghadapi Penyebaran Berita Hoax Covid-19. Media Keadilan: Jurnal Ilmu Hukum, 11(1), 98111. https://doi.org/10.31764/jmk.v11i1.2262

Rahayu, R. N., \& Sensusiyati, S. (2020). Analisis Berita Hoax Covid-19 Di Media Sosial Di Indonesia. Intelektiva: Jurnal Ekonomi, Sosial, \& Humaniora, 1(9), 6073.

Rahmat, H. K. (2019). Mobile learning berbasis Appypie sebagai inovasi media pendidikan untuk digital natives dalam perspektif Islam. Tarbawi: Jurnal Pendidikan Islam, 16(1), 33-50. https://doi.org/10.34001/tarbawi.v1i1.999

Rahmat, H. K., \& Alawiyah, D. (2020). Konseling Traumatik: Sebuah Strategi Guna Mereduksi Dampak Psikologis Korban Bencana Alam. Jurnal Mimbar: Media Intelektual Muslim Dan Bimbingan Rohani, 6(1), 34-44. https://doi.org/10.47435/mimbar.v6i1.372

Rahmat, H. K., Ramadhani, R. M., Ma'rufah, N., Gustaman, F. A. I., Sumantri, S. H., \& 
Adriyanto, A. (2020). Bantuan China Berupa Alat Uji Cepat Covid-19 Kepada Filipina: Perspektif Diplomacy and International Lobbying Theory. Jurnal Pendidikan Ilmu Sosial, 30(1), 19-27. https://doi.org/10.23917/jpis.v30i1.10623

Rayani, D., \& Purqoti, D. N. S. (2020). Kecemasan Keluarga Lansia Terhadap Berita Hoax Dimasa Pandemi COVID-19. REALITA: Jurnal Bimbingan Dan Konseling, 5(1), 906-912.

Rianto, P. (2019). Literasi digital dan etika media sosial di era post-truth. Interaksi: Jurnal Ilmu Komunikasi, 8(2), 24-35. https://doi.org/10.14710/interaksi.8.2.2435

Sabani, N. (2018). Generasi millenial dan absurditas debat kusir virtual. INFORMASI: Kajian Ilmu Komunikasi, 48(1), 95-108. https://doi.org/10.21831/informasi.v48i1.1 8078

Sutarto, S., Sari, D. P., \& Fathurrochman, I. (2020). Teacher strategies in online learning to increase students' interest in learning during COVID-19 pandemic. Jurnal Konseling Dan Pendidikan, 8(3), 129-137. https://doi.org/10.29210/147800

Syarifudin, A. S. (2020). Impelementasi Pembelajaran Daring Untuk Meningkatkan Mutu Pendidikan Sebagai Dampak Diterapkannya Social Distancing. Jurnal Pendidikan Bahasa Dan Sastra Indonesia Metalingua, 5(1), 31-34. https://doi.org/10.21107/metalingua.v5i1. 7072

Utama, D. B., Prewito, H. B., Pratikno, H., Kurniadi, Y. U., \& Rahmat, H. K. (2020). Kapasitas pemerintah Desa Dermaji Kabupaten Banyumas dalam pengurangan risiko bencana. Nusantara: Jurnal Ilmu Pengetahuan Sosial, 7(3), 591-606. Retrieved from http://jurnal.umtapsel.ac.id/index.php/nusantara/article/vi ew/1984

Witro, D. (2019). ISLAMIC RELIGIOUS EDUCATION IN THE FAMILY TO STRENGTHEN NATIONAL RESILIENCE OF SURAH AT-TAHRIM
VERSE 6 PERSPECTIVE. AlMuaddib:Jurnal Ilmu-Ilmu Sosial Dan Keislaman, 4(2), 306-315.

Zulfa, V., \& Laras, P. (2020). Schoology and Slido: The Perfect Platform Combination for Distance Learning During the Covid19 Pandemic. Advances in Engineering Research, 196(1), 86-91. https://doi.org/10.2991/aer.k.201124.016 